\title{
Father- child - interaction with their pre-school children
}

\section{DHRAKSHAYANI}

Received: 12.12.2014; Accepted: 09.05.2015

Author for correspondence: M. DHRAKSHAYANI Department of Home Science, Post Graduate Government College for Girls, CHANDIGARH (U.T.) INDIA

Email: sushaingoldy@yahoo.co.in
ABSTRACT : Although the importance of father's influence in child development is now generally accepted, we actually know very little about Father - Child - Interaction (F-C - I). This study aims to study Father - Child - Interaction with their pre-school children under natural conditions of home in middle class families. For the present study Belsky scale (1997) of F - C I was used to study F-C - I in 120 Indian families. Results reveal that majority of the fathers were involved in teaching, disciplining and socialization when compared to attending to the physical needs and play activities of the child during one hour home observation studies.

- KEY WORDS: Father child interaction, Care taking, Playing, Teaching, Disciplining, Socialization

- HOW TO CITE THIS PAPER : Dhrakshayani, M. (2015). Father - child - interaction with their pre-school children. Asian J. Home Sci., 10 (1) : 245-249. 